\title{
206. Zur Therapie der traumatischen Duodenalruptur
}

\author{
D. Kupczyk, T. Raguse und M. Froemel \\ Abteilung Chirurgie, Medizinische Fakultät der RWTH Aachen, Goethestraße 27-29, D-5100 Aachen
}

\section{Therapy of Traumatic Duodenal Perforation}

Summary. Traumatic duodenal perforation has an incidence of $1 \%-17 \%$ (blunt injury) or $1.7 \%-5 \%$ (penetrating injury). Its prognosis correlates to the kind of injury, associated injuries, size of perforation and delayed diagnosis. Mortality in cases of delayed repair is $65 \%$ compared with $5 \%$ mortality in early repaired perforation. In cases of delayed diagnosis, we recommend drainage of the perforation, naso-duodenal suction tube, parenteral alimentation. Four patients where diagnosis was delayed for 8 days or longer were treated in this way and the duodenal wound healed completely without any complications within 22-44 days.

Key words: Traumatic duodenal perforation - Delayed diagnosis - Therapy.

Zusammenfassumg. Die traumatische Duodenalruptur hat eine Inzidenz von 1-17\% (stumpfes Trauma) bzw. $1,7-5 \%$ (offenes Trauma). Thre Prognose ist abhängig von der Entstehungsweise, den Begleitverletzungen, der Ausdehnung der Ruptur und wesentlich von der Dauer der diagnostischen Latenz. Späterfaßte Rupturen sind in $65 \%$ letal, früherfaßte in $5 \%$. Unsere Therapiekonzept der späterfaßten Ruptur ist die Zieldrainage und die permanente Sekretableitung über eine nasoduodenale Sonde sowie die parenterale Ernährung. Bei allen 4 so behandelten Patienten mit mindestens 8 Tage alter Duodenalruptur komplette und folgenlose Rupturabheilung innerhalb 22-44 Tagen.

Schlüsselwörter: Verschleppte traumatische Duodenalruptur - Therapeutisches Konzept.

207. G. Schattenmann, D. Geile, M. Bader, B. Ultsch, München: Perianale Komplikationen beim Morbus Crohn.

Manuskript nicht eingegangen

\section{Neue Wege in der Behandlung Crohnbedingter Rectum- und Analfisteln}

\author{
W.-D. Hamperl und W. Kruis \\ Chirurgische Klinik der Universität München, Klinikum Großhadern, II. Medizinische Universität, \\ Marchioninistraße 15, D-8000 München 70
}

\section{New Aspects in the Treatment of Perianal Fistulas in Crohn's Disease}

Summary. Our sample consists of 289 patients with Crohn's disease, 172 patients admitted to the surgical and 117 to the medical department. Perianal fistulas were found in $25 \%$; the incidence was higher in the surgical than in the medical group. Of these patients, $65 \%$ had a colitis, whereas $35 \%$ had an ileitis. In $75 \%$, perinalal fistulas were the first symptom to be found, either in the first appearance of the disease or cases of recurrence. In about $75 \%$ of patients ( $n=49$, surgically treated) the surgical treatment proved to be unsuccessful as regards recidivism, loss of continence or stenosis. Conservative treatment $(n=25$, since 1976) with small incisions, however produced good results in $76 \%$ patients with fistulas. For these reasons, we prefer the conservative treatment of perianal fistulas to the radical surgical procedures.

Key words: Perianal fistulas - Crohn's disease - Conservative treatment.

Zusammenfassung. Das Krankengut umfaßt 289 Patienten, 172 der Chirurgischen und 117 Patienten der II. Medizinischen Klinik der Universität München im Klinikum Großhadern. Rectum- und Analfisteln fanden wir bei insgesamt $25 \%$ unserer Patienten, wobei die Incidenz im chirurgischen Krankengut höher $(28,4 \%)$ lag. Bei $65 \%$ der Patienten lag eine Colitis Crohn, in $35 \%$ eine Ileitis Crohn vor. In $75 \%$ waren die Fisteln erste Zeichen der Erkrankung oder eines Rezidivs. Das Therapieergebnis der operativ versorgten Patienten $(n=49)$ führte in $3 / 4$ der Fälle zu Mißerfolgen : Rezidive, Kontinenzverlust, Stenosebildung. Im Gegensatz dazu zeigten die konservativ behandelten Patienten $(n=25$, seit 1976) in $76 \%$ ein gutes Ergebnis. Deshalb ist neben der Behandlung der Grunderkrankung der konservativen Fisteltherapie der Vorzug vor den radikalen chirurgischen Verfahren zu geben.

Schliisselwörter: Rectum- und Analfisteln - Morbus Crohn - Konservative Therapie. 